\title{
Strategy, Meta-strategy and Anti-capitalist Activism Rethinking Leninism by Re-reading Lenin
}

\author{
STEPHEN D'ARCY \\ Department of Philosophy, Huron University College, London, Ontario, Canada
}

\begin{abstract}
Whereas Marxism is a theory, or rather a cluster of theories, Leninism is something else: a political strategy. And as Lenin himself pointed out, strategies are neither true nor false, but only effective or ineffective, depending largely on the context within which they are carried out. In the context of today's North America, however, the adoption by radical activists of the standard Leninist norms for anti-capitalist organizing would be counter-productive. What is needed now is a very different approach: a strategy of attrition, as Lenin would have said, rather than a strategy of overthrow. This article concludes by sketching an attrition strategy for contemporary anti-capitalist activism.
\end{abstract}

\section{Résumé}

Tandis que le marxisme est une théorie, ou plutôt un agrégat de théories, le léninisme est autre chose: une stratégie politique. Et, comme Lénine lui-même l'a souligné, les stratégies sont ni vraies ni fausses, mais seulement efficaces ou pas efficaces, en fonction du contexte dans lequel elles sont mises en œuvre. Toutefois, dans le contexte de l'Amérique du Nord d'aujourd'hui, l'adoption par des activistes radicaux des normes léninistes habituelles pour des mobilisations anti-capitalistes serait contre-productive. Une approche très différente est désormais nécessaire: une stratégie d'usure, comme Lénine l'aurait dit, au lieu d'une stratégie de renversement. Cet article conclut en esquissant une stratégie d'usure pour l'activisme anti-capitaliste contemporain.

\section{Keywords}

- Lenin • strategy $\bullet$ anti-capitalism $\bullet$ revolution $\bullet$ activism

Mots clés

- Lénine • stratégie • anti-capitalisme • révolution • activisme

\footnotetext{
Stephen D'Arcy is an Associate Professor in the Department of Philosophy at Huron University College, in London, Ontario, Canada. He teaches courses in moral and political philosophy and publishes in the areas of democratic theory and practical ethics. Correspondence: Department of Philosophy, Huron University College, 1349 Western Road, London, ON, N6G 1H3, Canada. E-mail: sdarcy@huron.uwo.ca.

Stephen D'Arcy est professeur associé dans le département de philosophie à Huron University College, in London, Ontario, Canada. II enseigne la philosophie morale et politique et publie dans les domaines de la théorie de la démocratie et de l'éthique appliquée. Correspondance: Department of Philosophy, Huron University College, 1349 Western Road, London, ON, N6G 1H3, Canada. E-mail: sdarcy@huron.uwo.ca.
} 
D'ARCY: Strategy, Meta-strategy, and Anti-capitalist Activism

Whereas Marxism is primarily a theory, or rather a cluster of theories, Leninism is something else: a political strategy. More specifically, Leninism is a political strategy for organizing radicals in pursuit of anti-capitalist revolution. In this paper I want to suggest a differentiated way of thinking about the kind of strategy proposed by Lenin. My aim is not historical. I make very little attempt to situate Lenin's thinking in its original social context. Rather, my aim is forward-looking and political. I want to clarify the relevance of Lenin's strategic framework for today's anti-capitalist activism.

I say 'anti-capitalist activism,' rather than 'socialist activism,' for two reasons. First, today many of those who identify as 'socialists,' especially those who adopt the label 'democratic socialists,' do not actually advocate an egalitarian post-capitalist economic democracy, but only an expansive welfare state variant of capitalism. For these socialists, questions of revolutionary strategy such as those addressed in this paper do not arise at all. Second, and conversely, many of those who today advocate dismantling capitalism and replacing it with an egalitarian postcapitalist economic democracy do not use the word 'socialism' to designate their project, preferring terms like 'participatory economics' (Albert 2000), 'equitable cooperation' (Hahnel 2005), 'a self-governing society' (Devine 1988), 'economic democracy' (Schweickart 2002), 'communalism' (Bookchin 2002), and so on. My concern is revolutionary strategy - the development of a strategy for defeating capitalism and replacing it with a democratic and egalitarian post-capitalist alternative - and it is the expression 'anti-capitalism' rather than 'socialism' that most lucidly and unambiguously picks out the relevant political project (Callinicos 2003). Nevertheless, if by 'socialism' one means 'egalitarian post-capitalist economic democracy,' everything that I say about 'anti-capitalist activism' may be taken to apply to 'socialist activism.'

Given the distance that separates the situation of revolutionaries in Lenin's time and context from the predicament of their counterparts in contemporary North America, extracting insights from Lenin's work to guide today's anti-capitalist revolutionaries is no simple matter, and here I propose to proceed in a new way. In essence, my proposal is to divide Lenin's strategic thinking into two levels, which I call the first-order and the second-order levels, respectively. It is not a distinction to which Lenin draws attention. But it is operative or 'at work' in what he says, and we can better understand what he does say if we keep the distinction in mind, as I hope to show. 
Socialist Studies: the Journal of the Society for Socialist Studies 5(2): 64-89

As I use these terms, first-order strategic analysis proposes direct guidelines or prescriptions for political action, whereas second-order strategic analysis proposes guidelines not for political action, but for strategy development itself. Second-order strategic analysis, in short, does not propose strategies; it proposes general criteria for choosing among strategies, for counting some strategies as sound and others as illconsidered. This first-order/second-order distinction calls attention to the difference, as we might also put it, between pragmatically determined strategy and social-theoretically determined meta-strategy.

Consider a quick example, to clarify the contrast. If I suggest that a campaign of escalating disruptive direct action will force local politicians to reconsider their plans to implement a certain controversial measure, I am proposing a first-order strategy ${ }^{1}$, designed to guide the conduct of a conflict toward a successful outcome for one side. But suppose I instead suggest that the way to choose between rival strategic proposals is to identify the balance of forces between advocates and adversaries of the controversial measure, and to opt in favour of whichever proposed course of action (or first-order strategy) would maximize the capacity of the measure's opponents to resist its implementation, and minimize the capacity of the measure's advocates to carry out its implementation. This second suggestion makes a proposal on a different level altogether, the 'secondorder' or 'meta-strategic' level. On its own it tells us nothing about what is to be done. It does not itself propose or constitute a strategy but rather offers guidelines for directing the development or selection of a suitable strategy.

In what follows, I begin by elucidating both Lenin's first-order revolutionary strategy, which is usually called 'Leninism,' and his secondorder analysis of how to develop or choose a first-order strategy under various circumstances. I then review Lenin's distinction (borrowed from Karl Kautsky) between strategies of attrition and strategies of overthrow. Against this background, I then suggest that Lenin's second-order metastrategy implies that anti-capitalist activism in our own time should repudiate first-order Leninism, which is a strategy of overthrow, in favour

\footnotetext{
${ }^{1}$ By 'strategy,' I mean an action-guiding proposal for how to mobilize political capacities (forces, resources, opportunities) and deploy political tactics (strikes, demonstrations, civil disobedience, public advocacy campaigns, and so on) in order to achieve an outcome favourable to one side in a conflict. Tactics are methods used to advance a strategy. Note that a tactic can be either brief in duration (like a protest march) or extended over many years (like publishing a monthly magazine). Strategies, too, can be short-range (like an insurrectionary strategy) or long-range (like a protracted guerrilla warfare strategy).
} 
D'ARCY: Strategy, Meta-strategy, and Anti-capitalist Activism

of a strategy of attrition. Finally turning my attention to today's anticapitalist movement, I briefly outline the elements of a strategy of anticapitalist attrition, as a first-order revolutionary strategy for our own nonrevolutionary times, which deviates from Lenin's first-order strategy precisely because it complies with his meta-strategy.

\section{Lenin's Principles of Strategy and Meta-Strategy}

When one says 'Leninism,' one does not usually mean Lenin's world-view, with its 'copy' theory of knowledge (Lenin 1909), its 'dialectical materialism' (Lenin 1914), its progress-relativist theory of morality (Lenin 1920c), its 'labour aristocracy' theory of opportunism (Lenin 1917a), and so on. Rather, by 'Leninism' one usually means only the first-order revolutionary strategy proposed by Lenin, especially as this took its mature shape, and to some extent underwent a certain codification, in the context of the early congresses of the Communist International.

No doubt, some will object to my account - or to any particular account - of first-order Leninism, but I believe that a relatively uncontroversial characterization of some of the key elements of this firstorder strategy can be stated in the form of six strategic principles for revolutionary activism plus one grand-strategic line of march. By 'grand strategy' I mean an overall account of the character of the revolutionary project in a particular time and place, which prescribes a particular developmental trajectory for the revolutionary movement: a wide-lens story of how we get from here to there. Lenin's grand-strategic line of march looks to the global working class, with its strategically sensitive location at the centre of the capitalist mode of production, to be the leading force of a broader anti-capitalist alliance of workers with the impoverished peasantry and other exploited 'intermediate classes.' This alliance, led by the political forces of a hegemonic working class, would pursue an ambitious transformative project, with two aspects. First, it would bring to completion by revolutionary means the democratic agenda that had been abandoned by capitalism's elites, including displacing autocratic regimes with democratic republics under universal suffrage, securing equal civil rights for all citizens, redistributing land to the peasants, and winning selfdetermination for oppressed nations. Second, it would use state power to push the democratic revolution - either very quickly (see Lenin 1917b) or in a later stage of an extended revolutionary process (see Lenin 1905) - to burst the bounds of liberal capitalism and undertake the expropriation of the capitalist class and the construction of a post-capitalist, socialist 
Socialist Studies: the Journal of the Society for Socialist Studies 5(2): 64-89

political and economic order on a global scale. This grand strategy is not central to my argument in this paper, since what is most distinctive about Lenin's first-order strategy is its particular set of organizational prescriptions, not its prescriptions about the overall line of march for working-class revolution against capitalism, a grand strategy that was in its essentials already articulated by Marx and Engels (1848). The six (largely organizational) strategic principles that comprise the most distinctive and controversial elements of Lenin's first-order strategy are as follows:

1. First, that the organizational form of the political party should be the central vehicle for leading the anti-capitalist movement, rather than, say, unions or cooperatives, as proposed by some syndicalists, anarchists and others (Lenin 1920b).

2. Second, that the party should be a party of the most advanced activists in the workers' movement, rather than a party of the working class as a whole, contrary to the views of radical social democrats in our contemporary sense (Lenin 1904).

3. Third, that the party should be centralist in matters of practical policy, not pluralist (Lenin 1921).

4. Fourth, that the party's centralism should be regulated by a command-and-control hierarchy of party governance, with lower level bodies acting under the direction of higher level bodies (Lenin 1904).

5. Fifth, that the party should try to participate in and exert influence on mass organizations of the workers' movement (such as unions and cooperatives), rather than to construct revolutionary alternatives to those organizations (Lenin 1920a).

6. And, finally, sixth, that the party's work ought to be integrated into, and ideally coordinated directly with, a wider process of global anticapitalist revolution, in the form of organized and disciplined internationalism, of the sort typified by the early Communist International (Lenin 1920d).

This, I take it, comprises the core of Lenin's first-order revolutionary strategy. These six principles (joined to the grand strategy sketched above) are enough to bring into focus the outlines of Lenin's strategy, with its familiar picture of a global workers' movement led by its so-called vanguard of radical activists, who are organized into a democratic centralist party, disciplined internally, but also internationally, by the norm of unity in action. This is 'Leninism.' 
And yet, there is more to Lenin's overall strategic framework than can be gleaned directly from this first-order strategy. And our reception of first-order Leninism ought to be informed by an appreciation of Lenin's thinking on strategy choice and strategy development, that is, by an appreciation of his second-order meta-strategy.

For my purposes, five of Lenin's meta-strategic principles stand out as especially important.

1. First, that the criterion of soundness in matters of strategy is not epistemic correctness (truth), but pragmatic efficacy (Lenin 1906).

2. Second, that pragmatic soundness is always context-relative, in the sense that a strategy that is sound in one context may be unsound in another (Lenin 1906).

3. Third, that the crucial contextual variable in assessing revolutionary strategies is, precisely, the balance of forces between the contending classes and their allied social forces (Lenin 1910).

4. Fourth, that as long as the balance of forces favours the ruling class and its allied social forces, the revolutionary struggle must be preparatory in nature, and hence protracted and asymmetrical, but as soon as the balance of forces favours the oppositional class and its allied forces, so that a rapid and fundamental strategic reversal seems possible, the struggle passes from a preparatory into a critical phase (Lenin 1910).

5. Fifth, that the strategic orientation appropriate to protracted and asymmetrical struggle, that is, to the preparatory phase of anticapitalist struggle, is that of an attrition strategy, whereas the strategic orientation appropriate to the critical phase of anticapitalist struggle is that of an overthrow strategy (Lenin 1910).

I take it that some of these points are self-evident, and require no special comment, notably the first three of Lenin's second-order principles, which jointly constitute a doctrine that we may call 'strategic contextualism': that strategies are neither true nor false, but only effective or ineffective; that effectiveness depends crucially on socio-political context; and that the decisive feature of the social context is the balance of power between the ruling class and the exploited and oppressed masses. But some of Lenin's meta-strategic principles make reference to political debates and strategic concepts that are less well-known, notably the distinction between preparatory and crisis phases of the anti-capitalist struggle and the further and related distinction between attrition and overthrow strategies. 
Socialist Studies: the Journal of the Society for Socialist Studies 5(2): 64-89

\section{Attrition and Overthrow}

Lenin's distinction between 'attrition' and 'overthrow' originated in the discourse of the German military historian Hans Delbrück (1848-1929). According to Delbrück, a strategy of overthrow (Niederwerfungsstrategie) proceeds by seeking out opportunities to confront the enemy directly in order to defeat it in decisive battles by overpowering its capacity to resist. A strategy of attrition (Ermattungsstrategie), by contrast, attempts to avoid or delay such decisive battles, usually because these cannot yet be won, and seeks instead to exploit every opportunity to strengthen the forces of the weaker side and to weaken those of their stronger enemy (Craig 1986). These terms, and the contrast between them, were borrowed from Delbrück and introduced into debates about socialist strategy by Karl Kautsky in 1910. Kautsky explained the distinction as follows:

Modern military science [viz., Delbrück] distinguishes between two kinds of strategy: the strategy of overthrow and the strategy of attrition. The former draws its forces rapidly together in order to go to meet the enemy and to deal decisive blows by means of which the enemy is overthrown and rendered incapable of struggle. In the attrition strategy, the commander-in-chief initially avoids any decisive battle; he aims to keep the opposing army on the move by all sorts of manoeuvres, without giving it the opportunity of raising the morale of its troops by gaining victories; he strives to gradually wear them out by continual exhaustion and threats and to consistently reduce their resistance and paralyse them. (Kautsky 1910, 54)

The occasion for Kautsky's introduction of the attrition/overthrow distinction was a debate between himself and Rosa Luxemburg, over how best to advance the aim of winning universal suffrage across Germany (Anderson 1976; Kautsky 1910; Luxemburg 1910). Luxemburg's favoured strategy, informed by the experience of the 1905 revolutionary movement in Russia, relied crucially on the use of militant mass strikes. In Kautsky's view, such a course of action would have been 'imprudent' (Kautsky 1910, 70), because Luxemburg's supposed 'overthrow' approach risked provoking a wave of state repression and anti-socialist legislation, in a context in which the radical Left might be unable to prevail. As a result, he argued, Luxemburg's strategy would have squandered the considerable gains that had been made over the years by the German Left. 'The worst defeat would be...if we summoned the proletariat to the political mass strike and it did not respond to the appeal by an overwhelming majority,' Kautsky argued. 'We would nip in the bud all the promising seeds being nurtured in the coming Reichstag elections if, without it being necessary, 
we provoked struggles which brought us heavy defeats... Today our agitation must escalate not towards the mass strike, but towards the coming Reichstag elections' (Kautsky 1910, 71). Thus, the term 'attrition' was first introduced into strategy debates on the Left in order to justify a rejection of militancy in favour of a passive, electoralist strategy, ${ }^{2}$ like that proposed by Kautsky.

In spite of this inauspicious introduction of Delbrück's vocabulary into strategy debates on the Left, Lenin cites the distinction approvingly later in that same year, in his article, 'The Historical Meaning of the InnerParty Struggle' (Lenin 1910). Lenin's purpose, we should note, is not to intervene into the strategy quarrel in Germany. Rather, as the context makes clear, Lenin's aim is only to chastise the Menshevik Julius Martov for misappropriating Kautsky's notion of attrition in the context of Russian debates about the 1905 revolt in Russia. It is quite correct to deploy the notion of attrition, Lenin suggests, but Kautsky rightly saw attrition strategies as appropriate only for preparatory phases of the struggle, when power asymmetries were to the great disadvantage of anti-capitalists. By contrast, Lenin says, 'Martov ... advocated the 'strategy of attrition' for the period when the revolution reached its highest intensity' (Lenin 1910, 383).

At this point, therefore, some caution is called for, to avoid a misreading of Lenin. True, Lenin endorses Kautsky's embrace of Delbrück's attrition/overthrow distinction. Moreover, Lenin also endorses Kautsky's insistence (in Kautsky 1910) that the anti-capitalist Left is not to choose between these strategic frameworks, but rather to sequence them correctly, switching from attrition to overthrow strategies when the preparatory phase gives way to a social crisis, opening up a path toward possible victory for the anti-capitalist Left (Lenin 1910). On these points, which are what I am calling meta-strategic points, Lenin follows Kautsky no less closely than Gramsci would go on to do some years later, in his prison notebooks (Gramsci 1971, 242-43 and throughout), where one of Delbrück's other names for attrition, 'war of position' (Stellungskrieg; see

\footnotetext{
${ }^{2}$ Note that Kautsky advocates electoralism as a strategy, not simply electioneering as a tactic: 'Our opponents are already reckoning with the possibility,' Kautsky said against Luxemburg, 'that in the coming election we will get 125 seats" (1910: 66). 'I have no doubt at all,' he added, 'that the next elections will shake this system to its foundations' (1910: 70). He was convinced 'that the earliest conceivable opportunity of inflicting a shattering blow to the worst enemies of the people, is the coming Reichstag elections; and that we should summon and rally all our forces for this end' (1910: 72).
} 
Delbrück 1918), is counterposed to 'war of maneuvre' 3 in a manner that follows Kautsky's text very closely indeed ${ }^{4}$ (Anderson 1976, 61-63). However, it would be wrong to jump to the further conclusion that Lenin would have endorsed - or that he actually did endorse - Kautsky's call for an attrition strategy in opposition to the overthrow stance of Luxemburg, in the context of the German debate. What we need to see here is that the case that Lenin makes against Martov - precisely when he embraces the attrition/overthrow contrast - is the very same case that Luxemburg makes against Kautsky. Luxemburg's hostility to Kautsky's call for an attrition strategy is, quite explicitly, bound up with an analysis of the balance of social power in the historical context of 1910 Germany. What Luxemburg says against Kautsky, and what Lenin says against Martov, is

${ }^{3}$ It should be pointed out that Gramsci's introduction of 'war of manoeuvre' as a name for the strategy of overthrow is potentially a source of confusion, because it exacerbates the likelihood that readers will confuse Kautsky's and Lenin's contrast between attrition strategies and overthrow strategies with the similar-sounding but actually very different contrast between 'wars of attrition' and 'wars of manoeuvre' as these terms are used by many contemporary military strategists (see Mearsheimer 1981/82; and Lind 1979). The trench warfare so typical of World War I exemplified the strategy of overthrow, not attrition, in Delbrück's sense, because each side sought to directly confront its adversary in order to overpower it. Yet, in the distinctly non-Delbrückian idiom of contemporary military strategists, World War I was a 'war of attrition.' To writers like Mearsheimer and Lind, a 'war of attrition' is - like Delbrück's strategy of overthrow - primarily focused on seeking out and conducting decisive battles, in a mutual test of strength. When they say 'war of manoeuvre,' on the other hand, they have in mind attempts to use bold and unexpected movements to strike suddenly at an adversary's 'Achilles heel,' leading to a rapid breakdown of the enemy's morale and system of command and control. Nevertheless, because the strategic discourse of the socialist Left has been shaped mainly by the usage familiar from writings by people like Kautsky, Gramsci, Luxemburg and Lenin, in this article I retain their Delbrückian vocabulary.

${ }^{4}$ Strangely, Anderson contends that Gramsci's recapitulation of Kautsky's attrition/overthrow argument was a mere 'coincidence,' albeit an 'arresting' and 'disconcerting' coincidence (6162). But this is by no means plausible. As Anderson himself points out, Gramsci's postion/manoeuvre contrast is not only formally analogous to Kautsky's attrition/overthrow contrast, but 'Kautsky evoked precisely the same historical and geographical contrasts as Gramsci was to do in his discussion of war of position and war of manoeuvre' (Anderson 1976, 62). It is perhaps not inconceivable that Gramsci - who was known to be an afficionado of strategy debates - was somehow unfamiliar with the Kautsky/Luxemburg debate over mass strikes (or Lenin's response to it in Lenin 1910). However, the burden of proof surely falls on anyone who, like Anderson, wants to claim that the arresting coincidence is indeed a mere coincidence, rather than (as seems more likely) a case of Gramsci simply adopting a view that had been popularized on the European Left by Kautsky and, within limits, endorsed by Lenin. Anderson does nothing to meet that burden of proof except simply to assert that, 'unknown to himself, Gramsci had an illustrious predecessor' in Kautsky (Anderson 1976, 61). 
that a sound meta-strategic principle - namely, that in the context of protracted, asymmetrical struggles against stronger adversaries an attrition strategy should be favoured over an overthrow strategy - is misappropriated by being pressed into service to defend a wrong-headed first-order strategy. ${ }^{5}$ Lenin and Luxemburg agree with Martov and Kautsky at the level of meta-strategy, but disagree at the level of strategy. And they disagree with the strategy primarily because the context is, in each case, not a context in which an unfavourable balance of power necessitates a protracted asymmetrical struggle against an adversary that is too strong to confront head-on. In both Lenin's reply to Martov (Lenin 1910) and Luxemburg's reply to Kautsky (Luxemburg 1910, part 2), the authors introduce evidence, such as strike levels and other data, to demonstrate that the workers' movement is stronger, and the ruling class is weaker, than Martov and Kautsky have suggested.

Moreover, it would also be a mistake to assume that, because Lenin endorsed the meta-strategic principle that attrition strategies are called for in prolonged non-revolutionary periods, he must have agreed with Kautsky's apparent assumption that an attrition strategy for the Left will be an electoralist one. In fact, agreement on meta-strategy does not imply agreement on first-order strategy: Lenin had a very different perspective on the place of electoral tactics in strategic planning for non-revolutionary periods and at no time did he endorse an electoralist strategy for any country, although he certainly favoured participation in elections as a tactic in many cases (Lenin 1920a).

\section{Lenin's Meta-strategy versus Lenin's Strategy}

What conclusions can we draw from the fact that Lenin embraced metastrategic principles quite close to those embraced by Kautsky and Martov? For one thing, this suggests that Lenin's commitment to first-order Leninism is not a function of supposedly timeless truths about how to maximize the effectiveness of anti-capitalist resistance. There are those (for example, Harnecker 2009) who deduce the core elements of firstorder Leninism from such timeless premises as the claim that institutionalized unity-in-action is more effective than strategic dispersal,

\footnotetext{
${ }^{5}$ Contrary to the suggestion of Anderson (1976), Luxemburg's evident resistance to Kautsky's use of Delbrück is not a rejection in principle of the attrition/overthrow distinction, but a rejection of its relevance to the contrast Kautsky draws between Russian and German conditions, a contrast that she depicts as simplistic and wrong-headed (see Luxemburg 1910).
} 
Socialist Studies: the Journal of the Society for Socialist Studies 5(2): 64-89

in multiple programmatically differentiated organizations, even when that differentiation is consistent with tactical concentration in united-front type activity. Arguably, that is not true as a generalization about effective political organizing. But in any case, it is not the basis for Lenin's firstorder strategy. On the contrary, Lenin hinges his case for first-order Leninism on its sensitivity to the demands of a particular context, namely, as he puts it against Martov, 'the period when the revolution reached its highest intensity.' More broadly, it is a strategy appropriate to what he calls 'an epoch of wars and revolutions' (Lenin 1916, 283), that is, a period of generalized social crisis, either underway or on the immediate horizon. ${ }^{6}$

The key point that I want to insist on is that Lenin's own mature strategic proposal, first-order Leninism, as codified in the early congresses of the Communist International, was an overthrow strategy which, by Lenin's own meta-strategic standards, ought to be suspended in contexts of protracted, asymmetrical struggle against a ruling class that is much more well-positioned strategically than the forces of the anti-capitalist opposition. In the latter circumstances, an attrition strategy is more suitable. Because it is clear, at least in reference to today's North America, that the balance of forces between the contending classes makes revolution an unlikely outcome in the foreseeable future, it is equally clear that Lenin's second-order strategic principles jointly imply, in the context of contemporary North American anti-capitalist activism, a strong case in favour of rejecting an overthrow strategy (such as first-order Leninism) and adopting instead an attrition strategy. In particular, several of Lenin's first-order principles - namely, the first, third, fourth, and sixth - have little

\footnotetext{
${ }^{6}$ By 'crisis,' in this context, I do not mean just any sort of crisis, such as a constitutional crisis or an economic crisis (although these can play a role as elements of a crisis in the present sense). Rather, I mean specifically the 'crisis phase of the anti-capitalist struggle,' which is to say any period in the history of a revolutionary movement in which the realistic possibility of actually carrying out revolution, as opposed to preparing for it, is on the historical agenda. Of course, even this notion is too vague to capture Lenin's thinking on this matter, because Lenin actually distinguishes between 'revolutionary periods,' such as the European epoch of wars and revolutions before, during and after World War I, and 'revolutionary situations,' in which the historical tasks of the 'crisis phase' become immediate requirements. These concepts are discussed in 'The Collapse of the Second International' (Lenin 1915): on 'revolutionary periods,' see 247; on 'revolutionary situations,' see 228 . In a revolutionary period the task is to prepare for a revolutionary situation. The latter may only obtain for 'days,' according to Lenin (270). 'History places this form of struggle on the order of the day very infrequently,' he says. But 'it will demand arduous preparatory activities' (270). An overthrow strategy is called for in revolutionary periods, precisely because in such periods it is necessary to prepare for a revolutionary situation, which is not the case during non-revolutionary periods.
} 
or no strategically sound application under circumstances where a firstorder strategy of attrition is called for. This is especially so under circumstances of legality (low levels of anti-radical repression).

Consider the first principle, that the political party is the central vehicle for leading the anti-capitalist movement. The whole conception of a 'political party' that Lenin takes for granted - whether he depicts as his paradigm case the Social Democratic Party of Germany (SPD) in the decades immediately prior to World War I or the Russian Communist Party after 1917 - presupposes that the party will be a mass organization, with real influence among millions of members of the working class. But a 'micro-party' of only a few hundred or a even a few thousand members will remain quite marginal to the many millions of workers in most countries. It is, therefore, a phenomenon of an entirely different type. Whatever the real or imaginary merits of micro-parties, it is clear that they have nothing to do with Lenin's notion of the Party as a vehicle for 'advanced workers' (i.e. militant workers, influenced by radical politics) to play a leadership role vis-à-vis the wider working class. So, in a context like that of present-day North America, in which no revolutionary 'party' that is more than a 'micro-party' has existed for many decades, this first principle of Lenin's first-order strategy has no application. Such a party cannot exist today or in the currently foreseeable future. Consider, too, the third and fourth principles, that a revolutionary organization should be centralist in two senses: 'non-pluralist' in matters of practical policy or program, and regulated by a command-and-control hierarchy of governance wherein lower-level bodies act under the direction of higher-level bodies. The rationale for these principles - which (together with a commitment to democratic decision-making after thorough discussion) jointly constitute the core of the complex notion of 'democratic centralism' - was always bound up, in Lenin's strategic thought, with strategic contextualism. It was the context - an 'epoch of wars and revolutions,' or what Lukács (1971) called 'the actuality of the revolution' - that made this kind of disciplined unity in action necessary. Disciplined centralism reflected the constraints associated with a life-and-death struggle against the ruling class and its political representatives. But under circumstances of legality (i.e. relatively mild political repression of radicals) and asymmetry (i.e. a weak Left confronting a powerful and entrenched ruling class) these constraints do not seem to hold. Indeed, by cultivating authoritarian personality traits among some activists, they may have the perverse effect over time of weakening the radical and militant impulses of revolutionary activists and creating a psycho-social 'disconnect' between revolutionaries and the 
Socialist Studies: the Journal of the Society for Socialist Studies 5(2): 64-89

wider working class. Consider, finally, the sixth of Lenin's first-order strategic principles, that the political conduct of revolutionary organizations in each country should be disciplined by a global coordinating body of the sort typified by the Comintern. This principle, too, is without application in a context in which the global radical Left, to say nothing of the North American radical Left, is far too weak to organize an 'International' of the sort represented by the Second and Third Internationals in Lenin's time. These Internationals brought together delegates from socialist mass parties in several countries. Nothing of that sort exists right now, and there is no reason to suppose that revolutionaries in North America have any sound reason to incorporate this notion - which was indeed relevant to radicals in Lenin's time - into their political strategy today.

It seems clear, therefore, that Lenin's first-order strategy has no application in contemporary North America, and we owe this insight to Lenin's own meta-strategic contextualism. As a matter of historical fact, after all, first-order Leninism proceeded from the assumption of the 'actuality of the revolution' (Lukács 1971), that is, the assumption that the anti-capitalist movement is operating in an 'epoch of wars and revolutions' (Lenin 1916). In contemporary North America, by contrast, a very different strategy is required: a strategy of anti-capitalist attrition. But, as always, meta-strategic principles of this kind imply no determinate directives on matters of first-order strategy. We can see clearly that a 'Leninesque' metastrategy implies that we should embrace an attrition strategy of some sort. But what sort of attrition strategy, exactly? What might a first-order strategy of anti-capitalist attrition look like, grounded in a Leninesque, and therefore also a Kautskyist and Martovian, meta-strategy, applied to contemporary North American conditions?

\section{Anti-Capitalist Attrition: Revolutionary Strategy in a Non-revolutionary Period}

There is, to be sure, something paradoxical about the task of formulating a revolutionary strategy for a non-revolutionary period. Intuitively, we expect that a revolutionary strategy will define success as the carrying out of a revolutionary transformation of society. But an attrition strategy - at least as Lenin understood it - starts out with the assumption that carrying out an actual revolution is not on the immediate agenda for anti-capitalist activists. In today's North America, there is no mistaking the predicament of those who aim to overturn the power of big business and to establish a 
radically democratic alternative to capitalism: the forces of the radical Left are in disarray, whereas the strength and confidence of the ruling class, though shaken by recent events (namely, the financial and macroeconomic crises of 2008-09), remain formidable indeed by comparison. The asymmetry between the power of an entrenched ruling class and the relative weakness of the anti-capitalist opposition poses a more modest, but equally challenging task: to develop a strategy for reversing this unfavourable balance of forces, to the advantage of the radical Left, so that the more ambitious project of attempting the 'overthrow' of capitalist rule can once again be taken up by anti-capitalists.

Obviously, the meta-strategically motivated decision to 'hold off' on pursuing an overthrow strategy has little in common with the position of those who regard the prospects for anti-capitalist revolution as so bleak that there is no point in pursuing revolutionary activism in this period. On the contrary, a strategy of anti-capitalist attrition is, precisely, a guide for conducting political action today with a view to laying the foundation for a revolutionary transformation in the future. Such a strategy will propose a set of strategic objectives, not on the grounds that revolution is impossible, but on the grounds that attaining these objectives will in fact open up a pathway toward a revival and reinvigoration of the revolutionary project. It is for this reason that an anti-capitalist attrition strategy, in the context of an asymmetrical and protracted struggle against an entrenched ruling class, is indeed a revolutionary strategy, even if it is not an overthrow strategy. ${ }^{7}$

Today's revolutionaries need an attrition strategy because they need to rebuild the radical Left, to revive the socialist project, to renew the movement to dismantle capitalism and replace it with a radically egalitarian, post-capitalist economic democracy. Today's tasks, in other words, are preparatory in nature. A strategy of anti-capitalist attrition can serve as a guide to this kind of preparatory revolutionary activism, offering activists a much-needed sense of orientation in strategic space: a framework for setting goals, developing tactics, choosing allies, assessing the movement's strengths and weaknesses, and identifying the period's dangers and opportunities.

\footnotetext{
${ }^{7}$ As discussed in above, to the extent that Kautsky and Martov advocated attrition strategies indeed, narrowly electoralist ones at that - in a context in which 'the revolution reached its highest intensity,' they were in fact disavowing the whole idea of transitioning from an attrition strategy into an overthrow strategy in the context of a revolutionary period. In that sense, these were clearly not revolutionary strategies, except in name.
} 
Socialist Studies: the Journal of the Society for Socialist Studies 5(2): 64-89

How, then, might North American revolutionaries proceed in the contemporary context? What kind of strategic objectives could they pursue in the hope of reversing today's unfavourable balance of forces?

Before identifying a set of objectives, it is necessary to take stock of just what we mean when we talk about a 'powerful' and 'entrenched' ruling class and a "weak" radical Left. Successfully identifying the sources of this imbalance should make it easier to identify the changes that would have to be brought about in order to achieve the core aim of any attrition strategy - to strengthen the weaker side and weaken the stronger side in an asymmetrical conflict.

I suggest that the strength of the North American ruling class, and the weakness of its anti-capitalist opposition, is rooted in four key features of the contemporary situation. First, we are living in a time of relative social stability, rather than a time of great upheaval and unrest, and this has been so for decades. That is not to say that there is no class conflict or significant social protest. Nor is it to deny the obvious economic dislocations and crises that continue to plague capitalism everywhere, indeed seldom more so than in the past couple of years. It is simply to take note of the obvious: that this is not a time of great social unrest and upheaval in North America. Second, the historical alternatives to capitalism are widely held to have been discredited, largely because the only two such alternatives that have been broadly acknowledged - welfare-state expansionism and bureaucratic command planning - have both fallen into a mostly-deserved state of broad disrepute (D'Arcy 2009). Third, the declining strength of the trade union movement, especially the private sector industrial unions, has meant that there is no united, organized social force that seems ready and able to challenge corporate power and fight for an alternative. And finally, fourth, the main historically important currents of anti-capitalist radicalism, such as anarchism and Marxism, that once exercised such a profound influence on masses of working-class activists, have in recent decades become almost entirely marginal to public political discourse in North America. This marginalization of anti-capitalist political currents has had the effect of allowing the ideology of capitalism's elites to go largely unchallenged by any coherent, visible, and credible alternative.

If these four circumstances are the sources of capitalism's strength in contemporary North America, then we know what anti-capitalists pursuing an attrition strategy will have to try to do. First, faced with levels of social upheaval and confrontational protest that are too low to pose the kinds of questions to which political radicalism purports to offer answers, today's anti-capitalists will have to destabilize the political order by 
fomenting sustained civil unrest. Second, faced with the discrediting of the leading historical alternatives to capitalism (namely, welfare-state expansionism and bureaucratic planning), anti-capitalist activists will have to construct prefigurative forms of egalitarian economic democracy, modelling sustainability and social justice, in order thereby to revive the lost sense of optimism about the viability and appeal of post-capitalist alternatives. Third, faced with the lack of a social force capable of confronting and challenging capitalism's ruling class and its underlings in government, anti-capitalists will have to construct an anti-corporate alliance of labour and community organizations, with the potential over the long run to contest the dominance and hegemony of big business. Finally, fourth, faced with the ideological marginalization of leftist challenges to capitalism, today's radicals will have to re-establish vital currents of anti-capitalist radicalism, and to begin to regain a capacity to exercise significant influence on activists on the broader Left, with the aim of re-inserting anti-capitalist ideas into the public sphere as a source of dissident analysis, vision and strategy.

Were anti-capitalist activists to succeed in carrying out these tasks, the resulting shift in the balance of forces between defenders and opponents of the capitalist system would be remarkable: it would signal the emergence of a strong Left, and an undermined, weakened ruling class. An anti-capitalist attrition strategy for North America under contemporary conditions, therefore, should aim to achieve these four strategic objectives: (1) fomenting civil unrest; (2) building prefigurative, non-capitalist alternatives; (3) constructing an anti-corporate alliance; and (4) reestablishing vital currents of anti-capitalist radicalism.

Enumerating these tasks is obviously easier than carrying them out, but anti-capitalists are by no means lacking in fruitful paths to follow with the aim of making real progress on these tasks. I will take up each in turn.

\section{Fomenting Civil Unrest}

Protest is at the heart of radical politics. The vitality of the Left relies crucially on the existence of powerful mass protest movements, which draw people into oppositional political activity, expose them to critical insights about how social institutions work, and in many cases transform their understanding of the prospects for participating directly in shaping the course of events by organizing resistance collectively with their neighbours, co-workers and allies. This relationship between the dynamism of the Left and the vitality of mass protest movements makes 
Socialist Studies: the Journal of the Society for Socialist Studies 5(2): 64-89

the decline of social protest in recent decades all the more troubling. Clearly an attrition strategy must address this problem.

Fortunately, anti-capitalist activists on the whole know better than most political activists how to foment civil unrest. After all, radicals have always played a leading role in fostering the development of militant mass mobilizations in which exploited and oppressed people take action to demand redress for their grievances. In recent years, too, anti-capitalists have had considerable success building grassroots protest movements by adopting the approach of combining strategic dispersal with tactical concentration. This was illustrated vividly in the organizing for the Seattle protest against the World Trade Organization (WTO) in November 1999. Strategic dispersal means cultivating the development of a pluralistic Left, comprised of multiple organizations, pursuing diverse agendas, favouring a wide range of tactics and organizing methods, and focusing on differentiated constituencies or audiences. Tactical concentration, on the other hand, means cultivating the capacity of this plurality of highly differentiated organizations and projects to engage in timely tactical convergence, uniting for coordinated action to advance an agreed upon aim in agreed upon ways at an agreed upon time and place. The global justice mass protests in cities like Seattle, Quebéc City, Washington, DC, Prague, and so on, in the period 1999-2001, all exemplified this approach.

And yet, even these successes have been fleeting and difficult to sustain. Building mass demonstrations is one thing; building and sustaining mass protest movements is something rather more difficult. Nevertheless, a resurgence of mass protest movements is a necessary condition for the revival of the prospects for a renewed revolutionary movement. If the Left has so far failed to achieve this resurgence, it is not because anti-capitalists do not know how to do it. After all, in 1999-2001, the Left was building the beginnings of a militant mass protest movement demanding global justice and opposing neo-liberalism. The emerging movement was derailed and disoriented by the events of 11 September 2001, but this could hardly have been predicted or avoided by the Left. Again, in late 2002 and early 2003, the scattered remnants of the global justice movement reconstituted themselves as a mass anti-war movement, which mobilized millions in an attempt to prevent the invasion of Iraq (D'Arcy 2008). In this case, the movement was derailed, not by an external shock, but by its inability to secure any unambiguous victories, a failure which dashed the hopes of many participants and took the steam out of the emerging movement. It is clear that a mass protest movement cannot be built without a string of victories to boost the confidence and sense of efficacy among organizers 
and actual or potential participants. But, notwithstanding their obvious limitations, both of these experiences with nascent mass movementbuilding in recent years should be seen as confirming that grassroots popular mobilization can be effective at politicizing millions of people and sparking a resurgence of mass protest movements. To be sure, there is no guarantee of success in these efforts. But neither is there any reason to doubt the possibility of success.

\section{Building Prefigurative, Non-capitalist Alternatives}

There is more to the Left than protest, of course. The Left has always aspired to point out a path toward a different kind of society: an egalitarian post-capitalist economy. We know, however, that the vision of a postcapitalist, socialist political and economic alternative to capitalism suffers from a crisis of credibility. There are some people who reject the idea of a socialist alternative because they regard it as fatally unworkable. But far more people reject socialism because they regard it as fundamentally unappealing. The experience of the social-democratic 'road' has given people an ample opportunity to experience the fruits of welfare-state expansionism. But, whatever the accomplishments of the bureaucratic welfare state, few people have found themselves drawn to it as an inspiring ideal of human liberation. The 'East European' model has been, if anything, still less inspiring than the welfare-state capitalism of the social-democrats. For these reasons, there can be little reason to expect a resurgence of the revolutionary anti-capitalist project unless radicals can develop a compelling case for the appeal of an egalitarian post-capitalist economy. But doing so will require going beyond rearticulating the familiar ideals of equality and democracy. It is necessary to take the further step of drawing masses of people into actually existing, and actually appealing, alternative economies. This means taking very seriously the task of building up the socalled 'social economy': workers' co-operatives, consumer and housing cooperatives, experiments in 'participatory economics,' small-scale barter economies, and other forms of democratic and egalitarian economic activity operating in the margins and interstices of contemporary capitalism (Gibson-Graham 2006). Marx rightly saw in co-operatives the seeds of a new, radically democratic and egalitarian alternative to capitalism (Marx 1894, Chapter 27), yet many self-described 'Marxists' pay almost no attention to the co-operative movement. The radical Left in the twentieth century, frankly, made a disastrous decision to drop its earlier commitment to co-operatives in favour of a bureaucratic-statist reinterpretation of the socialist ideal. A revitalized Left will have to do a 
Socialist Studies: the Journal of the Society for Socialist Studies 5(2): 64-89

much better job at promoting co-operatives and other prefigurative forms of economic democracy as living illustrations of the appeal of communitybased alternatives to profit-motivated market economics.

Though urgently necessary, such a renewal of the Left's commitment to co-operatives and other prefigurative, anti-capitalist economic forms will not be sufficient to revive the credibility of a socialist alternative to capitalism. Just as important is the building of an alternative politics. In the short term, that means systematically encouraging the development of an oppositional rather than an integrative politics: a channelling of popular political engagement away from the 'official' forms of political participation within the framework of the capitalist state, such as voting or joining electoralist parties, into specifically extraparliamentary modes of civic engagement, notably protest movement activism and other forms of grassroots, community-based civic activism. In the long term, though, building an alternative politics will mean fostering the re-emergence of counter-capitalist, parallel political institutions beyond the control of capital and the state, such as popular assemblies or community councils. This has been a hallmark of mass radicalizations for decades, as we have seen in so many of the major social upheavals of modern times (Gluckstein 1985; Barker 1987). Just as co-operatives and experiments in participatory economics can anticipate or prefigure possibilities for post-capitalist economic institutions and practices, so too can these community councils and assemblies anticipate participatorydemocratic modes of civic engagement in public policy-making in a postcapitalist context.

\section{Constructing an Anti-corporate Alliance}

Once again, there is no particular mystery about how to pursue the third strategic objective of the attrition strategy proposed here: constructing an anti-corporate alliance that is capable of posing a real threat to capitalism.

North American anti-capitalist activists are now a politically marginal and numerically tiny force. Yet the viability of their project depends on the participation of many millions of people. How can the radical Left link up its ambitious, transformative agenda with broad and politically efficacious forces capable (in the long run) of rivalling the economic power of big business and the political power of the capitalist state? Here a resurgent radical Left should embrace the good judgment of its earlier incarnations: the Left has traditionally identified as its potential base of mass support a broad sector of the public, consisting of the membership of working-class organizations, classically including unions 
and co-operatives but also encompassing other forms of working-class selforganization, and their 'natural allies' in those democratic and egalitarian community organizations working within civil society to achieve social and environmental justice, and political and economic democracy: feminists, anti-racists, environmentalists, disability-rights activists, and so on. This simply restates, in a contemporary idiom, the core of the 'grand-strategic line of march' that Lenin embraced and that I recounted above. This constituency has the two advantages of being both potentially receptive to anti-capitalist (or at least anti-corporate) politics, and potentially powerful in the threat that it can pose to the status quo. Unfortunately, the actual receptivity of that audience to anti-capitalist politics and the actual threat it poses to the status quo, fall far short of its potential in these respects. This, of course, is a problem with which 'Western Marxists' have been trying to grapple for many decades. My response to this set of problems is captured by the cumulative content of my comments on the first, second, and fourth strategic objectives of the anti-capitalist attrition strategy proposed in this paper (about fomenting civil unrest, building countercapitalist alternatives, and re-establishing vital currents of anti-capitalist radicalism). The constituency in question - working-class organizations and community-based social and environmental justice organizations - is no doubt demobilized and demoralized, but its resurgence represents the only hope for a transformative political project based upon the selforganization of exploited and oppressed people. So, whatever the difficulties, what anti-capitalists need to do is mobilize this constituency to build a powerful anti-corporate alliance of labour and community organizations.

It seems clear that such a labour/community alliance is necessary for a revival of the anti-capitalist project. But what, tactically speaking, can anti-capitalists do to build it? We can think of this in terms of the need to foster a double transformation: unions and other working-class organizations have to move in the direction of deeper and more consistent forms of solidarity with the wider circle of community-based movement activism within civil society; and these non-labour community organizations need to reject alliances with big business and its political representatives, and to embrace instead a consistently anti-corporate, proworker political analysis and strategy. Within the labour movement, this means that anti-capitalists need to challenge every manifestation of narrowly economic 'business unionism' by organizing at the rank and file level within unions for a 'solidarity' or 'social movement' approach to unionism, which besides focusing on bargaining for wages and benefits 
Socialist Studies: the Journal of the Society for Socialist Studies 5(2): 64-89

also gives priority to the promotion of a broader political agenda for democratizing the economy, and for promoting social movements against racism, sexism, poverty and environmental destruction. Conversely, within the wider civil society social movements, activists pursuing anti-capitalist attrition need to promote a consistently anti-corporate, pro-worker consciousness, as an indispensable element of Left politics generally. Thus, for example, they need to make the case for specifically class-struggle (militantly anti-corporate) forms of feminism, anti-racism, environmentalism, and so on. Doing so will sharpen the antagonism that divides participants in these movements from the economic and political elites of capitalism. But it will also enhance their capacity to win real gains by encouraging the development of a powerful strategic alliance with the workers' movement at the grassroots level.

Re-establishing Vital Currents of Anti-capitalist Radicalism I argued above that, in a preparatory period, when revolutionary politics has little influence on the vast majority of working-class people, it makes no sense to think that 'the role of the party' sketched by Lenin (1920b) has any contemporary relevance. There are no masses of radical workers to organize into a party of the 'advanced workers' (or 'vanguard of the working class'). So there is no party to build. Nevertheless, the fourth strategic objective of re-establishing vital currents of anti-capitalist radicalism, as sources of radical analysis, strategy, and vision, is at all times of crucial importance. The question is, how do we advance that aim in the present context?

First, anti-capitalists, starting from their position at the margins of public discourse, need to develop a voice: a capacity to convey their ideas about the world in ways that advance the project of radical social change. Here we can draw on Hal Draper's important and influential idea that, in a non-revolutionary time, the way to advance the socialist project is by creating, not a micro-party, but a 'political centre': a distinctive current of anti-capitalist radicalism, with its own identity and point of view, expressed in a body of literature and usually a periodical publication, and able to establish 'its "kind of socialism" as a presence in left politics' (Draper 1971). It is a matter, not of organization-building per se, but developing vital currents of socialist analysis, strategy, and vision, and then seeking to gain influence for this 'kind of socialism' among politicizing and radicalizing people, in the broader working class.

On the other hand, perhaps we can see today that all references to 'gaining influence' in the working class are in an important sense 
misleading. After all, the socialist movement has never made great advances by simply permeating the consciousness of workers, in a unilateral way. Rather, in its high points (the Revolutions of 1848, the Paris Commune of 1871, the 1905 and 1917 revolts in Russia, the events of May 1968 in France, to name only a few) it has moved forward by establishing a dialogical process of interchange between the pre-existing currents of anticapitalist radicalism and the so-called 'spontaneity' of grassroots political innovation by newly politicized and radicalizing people who do not simply throw their weight behind the 'leadership' or 'program' of existing radical organizations, but instead take initiatives and develop insights that are entirely their own. This suggests that re-establishing vital currents of anticapitalist radicalism must proceed in the form of a dialogical, reciprocal learning process between activists seeking to draw on existing political traditions (like Marxism, social anarchism, socialist-feminism, and so on) and newly politicizing people with whom they work in social movements, who may have their own ways of articulating their grievances and aspirations, and their own ideas about how society works or how best to change it.

These two imperatives - on the one hand, developing a voice, and on the other, cultivating a capacity to listen to others and learn from them - are what anti-capitalists need to address, as best they can, in order to make headway in re-establishing radical political currents with the capacity to speak to the concerns of wider circles of potential participants in the renewal of the radical Left.

This, then, is a sketch of a first-order strategy of anti-capitalist attrition that would be consistent with Lenin's strategic contextualism, and his meta-strategy as a whole. As an attrition strategy, it focuses on one basic goal: to strengthen the anti-capitalist Left while weakening the ruling class and its political representatives. In its strategic objectives, it obviously diverges sharply from first-order Leninism. But it is equally obvious - for reasons that Lenin well understood - that a serious approach to revolutionary strategy must do so, given the circumstances facing anticapitalist activists in contemporary North America.

\section{Conclusion}

I conclude with a general thought about how we might best think about Lenin in the contemporary context. Most people who identify as Leninists adopt an approach that focusses on the doctrinal content of Lenin's body of work, and the substantive practical or strategic 'lessons' of his political 
Socialist Studies: the Journal of the Society for Socialist Studies 5(2): 64-89

activism. But a better way might be to look to Lenin's work, not for doctrines to adopt or strategic dictums to follow, but for a model of how to develop a context-sensitive political strategy for the anti-capitalist Left. Learning from Lenin would then not be a matter of agreeing with what he says, but rather emulating the manner in which he goes about deciding what to say. What is interesting about Lenin, on this view, is that he starts from an analysis of the present-day trajectory of capitalist development, attentive to the balance of class forces and the strengths and weaknesses of the radical Left, and on this basis he develops a political strategy for anticapitalist organizing that is sensitive to the particularities of the present context. From this point of view, the impulse to find historically invariant first-order strategic principles in Lenin's work (about democratic centralism or party-building, for example) is fundamentally missing the point of what is most compelling about Lenin's approach to political strategy: it is to ignore the context-sensitivity and historical groundedness of his strategic prescriptions. It would be better, I suggest, to rethink Leninism by re-reading, more carefully, what Lenin says about anticapitalist meta-strategy, and heeding his advice.

\section{Acknowledgements}

I wish to thank Paul Le Blanc for helping me to see that the account I gave of Lenin's revolutionary strategy in an earlier version of this paper was too narrowly focused on organizational prescriptions, a problem that I have tried to correct, though not necessarily to an extent that would satisfy him. I also wish to thank Alex Levant for organizing the panels on Lenin at the 2009 annual meetings of the Society for Socialist Studies in Ottawa, which gave me a rare opportunity to take up questions of revolutionary strategy in an academic setting. I also thank the other panellists and the audience members for the lively and stimulating discussion on that occasion.

\section{References}

Albert, Michael. 2000. Moving Forward: Program for a Participatory Economy. Oakland: AK Press.

Anderson, Perry. 1976. "The Antinomies of Antonio Gramsci." New Left Review, I/100: 578.

Barker, Colin, ed. 1987. Revolutionary Rehearsals. London: Bookmarks.

Bookchin, Murray. 2002. “The Communalist Project.” In Eiglad and Bookchin 2007.

Callinicos, Alex. 2003. An Anti-capitalist Manifesto. Cambridge: Polity Press. 
D'ARCY: Strategy, Meta-strategy, and Anti-capitalist Activism

Craig, Gordon A. 1986. “Delbrück: The Military Historian.” In Paret 1986.

D’Arcy, Stephen. 2008. "The Militant Protester as Model Citizen," Peace Review: A Journal of Social Justice 20, no. 3: 292-299.

D’Arcy, Stephen. 2009. “The Renewal of Radical Politics," Relay 25: 30-32.

Delbrück, Hans. 1918. Krieg und Politick, 1914-16. Berlin: Georg Stilke.

Devine, Pat J. 1988. Democracy and Economic Planning: The Political Economy of a Selfgoverning Society. Boulder: Westview Press.

Draper, Hal. 1971. "Toward a New Beginning - On Another Road: The Alternative to the Micro-Sect." Available at Marxists Internet Archive, http://www.marxists.org/archive/draper/1971/alt/alt.htm/ (accessed 01 July 2009).

Eiglad, Eirik and Murray Bookchin. 2007. Social Ecology and Communalism. Oakland: AK Press.

Gibson-Graham, J.K. 2006. A Postcapitalist Politics. Minneapolis: University of Minnesota Press.

Gluckstein, Donny. 1985. The Western Soviets: Workers' Councils versus Parliament, 19151920. London: Bookmarks.

Goode, Patrick (ed.). 1983. Karl Kautsky: Selected Political Writings. London: Macmillan.

Gramsci, Antonio. 1971. Selections from the Prison Notebooks. New York: International Publishers.

Hahnel, Robin. 2005. Economic Justice and Democracy: From Competition to Cooperation. New York: Routledge.

Harnecker, Marta. 2009. "Should we Reject Bureaucratic Centralism and Simply Use Consensus?" Links. Available at http://links.org.au/node/1078/ (accessed 01 July 2009).

Kautsky, Karl. 1910. “The Mass Strike.” Reprinted in Goode 1983: 53-73.

Lenin, V.I. 1902. "What is to be Done? Burning Questions of our Movement." Reprinted in Lenin 1977, Volume 1: 92-241.

Lenin, V.I. 1904. “One Step Forward, Two Steps Back: The Crisis in Our Party.” Reprinted in Lenin 1977, Volume 1: 242-421.

Lenin, V.I. 1905. "Two Tactics of Social-Democracy in the Democratic Revolution." Reprinted in Lenin 1977, Volume 1: 425-527.

Lenin, V.I. 1906. "Guerrilla Warfare." Reprinted in Pomeroy 1968: 84-94.

Lenin, V.I. 1909/1964. Materialism and Empiro-Criticism: Critical Comments on a Reactionary Philosophy. Moscow: Progress Publishers.

Lenin, V.I. 1910. "The Historical Meaning of the Inner-Party Struggle in Russia." Reprinted in Lenin 1967, Volume 16: 374-92.

Lenin, V.I. 1914. "Karl Marx: A Brief Biographical Sketch with an Exposition of Marxism." Reprinted in Lenin 1977, Volume 1: 15-43. 
Socialist Studies: the Journal of the Society for Socialist Studies 5(2): 64-89

Lenin, V.I. 1915. "The Collapse of the Second International." Reprinted in Lenin 1959: 22176.

Lenin, V.I. 1916. "Opportunism and the Collapse of the Second International." Reprinted in Lenin 1959: 280-92.

Lenin, V.I. 1917a. "Imperialism, the Highest Stage of Capitalism: A Popular Outline." Reprinted in Lenin 1977, Volume 1: 634-731.

Lenin, V.I. 1917b. "The Tasks of the Proletariat in the Present Revolution." Reprinted in Lenin 1977, Volume 2: 29-33.

Lenin, V.I. 1920a. "Left-Wing Communism - An Infantile Disorder." Reprinted in Lenin 1977, Volume 3: 291-370.

Lenin, V.I. 1920b. "Speech on the Role of the Communist Party." Reprinted in Lenin 1972: 50-54.

Lenin, V.I. 1920c. "The Tasks of the Youth Leagues: Speech delivered at the Third AllRussia Congress of the Russian Young Communist League." Reprinted in Lenin 1977, Volume 3: 410-23.

Lenin, V.I. 1920d. "Report on the International Situation and the Fundamental Tasks of the Communist International." Reprinted in Lenin, 1977, Volume 3: 389-404.

Lenin, V.I. 1921. "Preliminary Draft Resolution of the Tenth Congress of the R.C.P. on Party Unity." Reprinted in Lenin 1977, Volume 3: 519-22

Lenin, V.I. 1959. Against Revisionism. Moscow: Foreign Languages Publishing House.

Lenin, V.I. 1967. Collected Works, $4^{\text {th }}$ English Edition, Translated and Edited by Clemens Dutt. Moscow: Progress Publishers.

Lenin, V.I. 1972. Speeches at Congresses of the Communist International. Moscow: Progress Publishers.

Lenin, V.I. 1977. Selected Works, Volumes 1-3. Moscow: Progress Publishers.

Lind, William S. 1979. "Military Doctrine, Force Structure, and the Defense DecisionMaking Process," Air University Review 30, no. 4: 21-27.

Lukács, Georg. 1971. Lenin: A Study on the Unity of his Thought. Cambridge, Massachusetts: MIT Press.

Luxemburg, Rosa. 1910. "Theory and Practice." Available at Marxists Internet Archive, http://www.marxists.org/archive/luxemburg/1910/theory-practice/ (accessed 01 July 2009).

Marx, Karl. 1894. Capital, Volume 3: The Process of Capitalist Production as a Whole. Friedrich Engels, ed. Available at Marxists Internet Archive, http://www.marxists.org/archive/marx/works/1894-c3/index.htm/ (accessed 01 July 2009).

Marx, Karl and Friedrich Engels. 1848. "Manifesto of the Communist Party." Reprinted in Marx and Engels 1974.

Marx, Karl and Frederick Engels. 1974. Selected Works (in one volume). New York: International Publishers. 
Mearsheimer, John. 1981/82. "Maneuver, Mobile Defense, and the NATO Central Front," International Security 6, no. 3: 104-122.

Paret, Peter, ed. 1986. Makers of Modern Strategy: From Machiavelli to the Nuclear Age. Oxford: Clarendon Press.

Pomeroy, William J. (ed.). 1968. Guerrilla Warfare and Marxism. New York: International Publishers.

Schweickart, David. 2002. After Capitalism. Oxford: Rowman and Littlefield. 